Other materials used on occasion as inhibitors of protein synthesis include amino-acid and nucleotide analogues. Neither azauridine (1 mmolar), 5-fluorouracil (10 $\mu$ molar), DL-norleucine $(20$ mmolar) nor DI-ethionine (20 mmolar) have any appreciable inhibitory influence on incorporation by diaphragm even during incubation periods as long as $6 \mathrm{~h}$. It could be argued that the materials do not readily penetrate the tissue - but the uptake of amino-acids is well established, the incorporation of nucleotides readily observable and the rapidity with which molecules as large as puromycin, actinomycin and cycloheximide exert their influence is impressive. Uptake of chloramphenicol by reticulocytes has recently been studied ${ }^{23}$.

Table 3. FFFECT OF INSULIN IN THE PRESENCE OF OYCLOHEXIMIDE ON THE ACCUMULATION AND INCORPORATION INTO PROTEIY OF ${ }^{14} \mathrm{C}-G L Y C I N E$ BY ISOLATED RAT DIAPHRAGM

$\begin{array}{cc}\text { Insulin } & \begin{array}{c}{ }^{14} \mathrm{C}-\mathrm{glycine} \text { accumulated } \\ \text { added }\end{array} \\ - & \left.\text { Ratio } \frac{\text { c.p.m./ml. tissue water }}{\text { c.p.m./ml. medium }}\right) \\ + & 2 \cdot 04 \pm 0 \cdot 18\} P=0.01\end{array}$

Radioactivity
incorporated into
protein
(c.p.m./mg protein)
$\left.\begin{array}{c}16 \cdot 5 \pm 0 \cdot 70 \\ 22 \cdot 3 \pm 1 \cdot 10\end{array}\right\}=0 \cdot 001$
The tissue was pre-incubated for 30 min in the presence of $2 \mu \mathrm{g} / \mathrm{ml}$. of cycloThe tissue was pre-incubated for 30 min in the presence
heximide before addition of the ${ }^{14} \mathrm{C}$-glycine $(0 \cdot 2 \mu \mathrm{l} . / \mathrm{ml}$.$) .$

Table 4. EFFECT OF ADMINISTRATION OF CYCLOHEXIMIDE in vivo ON THE CAPACITY OF THE SURSEQUENTLY ISOLATED DIAPHRAGM MUSCLE TO CORPORATE 1a C-GLYCINE INTO PROTEIN AND TO RESPOND TO INSULIN

\begin{tabular}{|c|c|c|c|}
\hline $\begin{array}{l}\text { Animals } \\
\text { injected with }\end{array}$ & $\begin{array}{l}\text { Isolated } \\
\text { diaphragm } \\
\text { with } \\
\text { insulin }\end{array}$ & $\begin{array}{l}\text { Uptake of glucose } \\
(\mathrm{mg} / \mathrm{g} \text { wet weight } / \mathrm{h})\end{array}$ & $\begin{array}{c}\text { Radioactivity } \\
\text { incorporated into } \\
\text { protein } \\
\text { (c.p.m./mg of protein) }\end{array}$ \\
\hline $\mathbf{l i}$ & - & $3 \cdot 58 \pm 0 \cdot 2$ & $\begin{array}{l}145 \\
243\end{array}$ \\
\hline$\theta \times 1$ & \pm & $\begin{array}{l}6 \cdot 38 \pm 0 \cdot 20 \\
2 \cdot 89 \pm 0 \cdot 31\end{array}$ & $\begin{array}{l}243 \\
21 \cdot 7 \pm 0.92\end{array}$ \\
\hline cloheximide & + & $6.55 \pm 0.17$ & 2010 \\
\hline
\end{tabular}

Cycloheximide
Each figure is the mean \pm standard error of mean of six observations.

as can be shown with puromycin ${ }^{17}$. A more important question is why ribosomal systems from animals treated with inhibitors exhibit incorporating capacity at all (for example, refs. 29, 30). Without a clearer understanding of the full enzymology of protein synthesis this is difficult to answer.

I thank Mrs K. Parkes for technical assistance and the Medical Research Council for financial support.

K. L. Manchester

Department of Biochemistry,

University College, I,ondon.

Received September $7,1967$.

${ }^{1}$ Borsook, H., Fischer, E. H., and Keighley, G., J. Biol, Chem., 229, 1059 (1957).

${ }^{2}$ Von Ehrenstein, G., and Lipmann, F., Proc. US Nat. Acad. Sci., 47, 941 (1961).

${ }^{3}$ Allen, E. H., and Schweet, R. S., J. Biol. Chem., 237, 760 (1962).

${ }^{4}$ Clark-Walker, G. D., and Linnane, A. W., Biochem. Biophys. Res. Commun. 25, $8(1966)$.

'Von der Decken, A., in Techniques in Protein Biosynthesis (edit. by Campbell, P. N., and Sargent, J. R.), 65 (Academic Press, 1967).

${ }^{6}$ Breuer, C. B., Davies, M. C., and Florini, J. R., Biochemistry, 3, 1713 (1964).

7 Earl, D. C. N., and Korner, A., Biochem. J., 94, 721 (1965).

- Florini, J. R., Biochemistry, 3, 209 (1964).

- Florini, J. R., and Breuer, C. B., Biochemistry, 4, 253 (1965).

${ }^{10}$ Kalf, G. F., Arch. Biochem. Biophys., 101, 350 (1963).

11 Kroon, A. M., Biochim. Biophys. Acta, 72,391 (1963)

${ }_{12}$ Manchester, K. L., Biochem. J., 88, 711 (1966).

13 Manchester, K. L., Biochem. J., 81, 135 (1961).

14 Manchester, K. L., and Young, F. G., Biochem. J., 75, 487 (1960).

${ }^{15}$ Wool, I. G., Castles, J. J., and Moyer, A. N., Biochim. Biophys, Acta, 107, 333 (1965).

${ }^{18}$ Manchester, K. L., Biochem. J., 90, 5C (1964).

17 Wool, I. G., and Moyer, A. N., Biochim. Biophys. Acta, 91, 248 (1964).

${ }^{18}$ Manchester, K. L., and Young, F. G., J. Endocrinol., 18, 381 (1959).

${ }^{19}$ Truman, D. E. S., and Löw, H., Exp. Cell Res., 31, 230 (1963).

${ }^{20}$ Weisberger, A. S., Armentrout, S., and Wolfe, S., Proc. US Nat. Acad. Sci., 50, 86 (1963).

21 Barnabei, O., and Sereni, F., Biochim. Biophys. Acta, 91, 239 (1964).

${ }^{22}$ Farese, R. V., Biochim. Biophys. Acta, 87, 699 (1964).

${ }^{23}$ Godchaux, W., and Herbert, E., J. Mol. Biol., 21, 537 (1967).

${ }^{24}$ Eboué-Bonis, D., Chambaut, A. M., Volfin, P., and Clauser, H., Nature, 199,1183 (1963).

${ }^{25}$ Elsas, L. J., Albrecht, I., Koehne, W., and Rosenberg, L. E., Nature, 214, 916 (1967).

${ }_{26}$ Castles, J. J, and Wool, I. G., Biochem, $J, 91,11 C$ (1964).

${ }^{27}$ Wool, I. G., and Cavicchi, P., Proc. US Nat. Acad. Sci., 56, 991 (1966).

${ }^{28}$ Garren, I. D., Ney, R. L., and Davis, W. W., Proc. US Nat. Acad. Sci., 53, $1443(1965)$.

${ }^{29}$ Korner, A., Biochem. J., 101, 627 (1966)

so 'Trakatellis, A. C., Montjar, M., and Axelrod, A. H., Biochemistry, 4, 2065 (1965).

and cycloheximide interfere with the response of muscle ribosomal system to insulin, and they suggest, by analogy with similar findings with adrenocorticotrophic hormone ${ }^{28}$, that a primary action of insulin is to promote formation of a labile protein which is responsible for increasing the activity of the polysomes. I have confirmed the findings ${ }^{25}$ of the inhibitory effect of puromycin and cycloheximide on accumulation of aminoisobutyrate (Table 2). But an effect of insulin to promote aminoisobutyrate accumulation remains observable, albeit on a smaller absolute scale, and promotion of glucose uptake is also seen. A normal percentage increase of incorporation by insulin is observable (Table 3 ) although it is reduced by pre-incubation with cycloheximide. When cycloheximide is administered in vivo before removal of the diaphragm, the tissue again responds to insulin both with respect to glucose uptake and amino-acid incorporation (Table 4). These observations do not support the concept that the primary actions of insulin on muscle, whatever they are, are dependent on proteins with a rapid rate of turnover and renewal. Because cyclo. heximide is thought to bind to ribosomes, a more mundane interpretation of the results of Wool and Cavicchi ${ }^{27}$ and possibly those of Garren et al. ${ }^{28}$ would be that the ribosomal systems isolated after treatment with cycloheximide remain contaminated with the inhibitor and, despite some apparent incorporating capacity, are effectively dead. In these conditions hormonal response is unlikely to be observed. The question remains why cycloheximide in vivo was not found totally to inhibit incorporation by diaphragm. This is probably a technical question of dosage

\section{Growth Hormone and Carbohydrate Metabolism in vitro}

IN the recent communication under this title, Bolodia and Young" say that ". . . no satisfactorily reproducible effect of growth hormone in vitro on carbohydrate metabolism has been described". No grounds are given for rejecting the comprehensive evidence of Ottaway and Bulbrook $^{2}$ for effects on the glucose uptake of rat diaphragm which are practically identical with those now described by Bolodia and Young, nor for the evidence of Bronk and Fisher $^{3}$ that very small concentrations of bovine growth hormone produce anti-insulin effects on the perfused rat heart. Bronk and Fisher showed that growth hormone reduced glucose uptake and permeability to galactose in the absence of insulin as well as in its presence. It follows that growth hormone produces an effect which offsets the action of insulin but is not acting as an anti-insulin.

\section{R. B. Fisher}

Department of Biochemistry, University of Edinburgh.

Received August 28, 1967.

${ }^{1}$ Bolodia, G., and Young, F. G., Nature, 215, 961 (1967).

${ }^{2}$ Ottaway, J. H., and Bulbrook, R. D., J. Endocrinol., 12, 50 (1955).

${ }^{3}$ Bronk, M. S., and Fisher, R. B., J. Physiol., 136, 435 (1957) 